\title{
Displacement length and velocity of tagged logs in the tagliamento river
}

\author{
Diego Ravazzolo,1 L. Mao, ${ }^{2}$ B. Garniga, ${ }^{1}$ L. Picco, ${ }^{1}$ M.A. Lenzi ${ }^{1}$ \\ 'Department of Land, Environment, Agriculture and Forestry, University of Padova, Padova, Italy \\ ${ }^{2}$ Department of Ecosystems and Environment, Pontificia Universidad Catolica de Chile, Santiago, \\ Chile
}

\begin{abstract}
Large wood enhance the dynamics of geomorphic processes in river systems, increases the morphological complexity of the channel bed, and provides habitats for fish and invertebrates. On the other side, if transported during high-magnitude events, large wood pieces can increase flood risks in sensitive places such as bridges and narrow cross sections prone to outbank flows. However, the dynamics and mobility of logs in rivers is poorly understood, especially in wide gravel-bed rivers. Recent studies have employed fixed video cameras to assess logs velocity, but little evidence is still available about travel length during flood events of different magnitude. This study was conducted in a valley reach of the Tagliamento river, located in the North East of Italy. The Tagliamento river is approximately $800 \mathrm{~m}$ wide in the study area, and is characterized by relatively high natural conditions and complex fluvial dynamics. Log mobility have been studied from June 2010 to October 2011, a period characterized by a relatively high magnitude flood in November 2010 . Log mobility and displacement during floods have been measured by implanting active radio transmitters (RFID) in 113 logs and GPS track devices in 42 logs. The first devices allow to recover the log after flood events by using a portable antenna, and to derive the displacement length over the monitoring period, whereas the second devices allows to calculate instantaneous (1 sec) and average log velocity of moving logs. Recovery rate of logs equipped with RFID and GPS was about $50 \%$ and $60 \%$, respectively. A preliminary analysis of the data collected indicates
\end{abstract}

Correspondence: Diego Ravazzolo, Department of Land, Environment, Agriculture and Forestry, University of Padova, Padova, Italy.

E-mail: diego.ravazzolo@studenti.unipd.it

Key words: Large wood transport, Tagliamento river, gravel-bed river, wood characteristics, tracking systems.

Aknowledgement: this research was founded by both the Italian National Research Project PRIN20104ALME4-ITSedErosion: "National network for monitoring, modeling and sustainable management of erosion processes in agricultural land and hilly-mountainous area"; and The EU SedAlp Project: "Sediment management in Alpine basis: Integrating sediment continuum, risk mitigation and hydropower",83-4-3-AT, in the framework of the European Territorial Cooperation Programme Alpine Space 2007-2013.

CC Copyright D. Ravazzolo et al., 2013

Licensee PAGEPress, Italy

Journal of Agricultural Engineering 2013; XLIV(s2):e10

doi:10.4081/jae.2013.s2.e10

This article is distributed under the terms of the Creative Commons Attribution Noncommercial License (by-nc 3.0) which permits any noncommercial use, distribution, and reproduction in any medium, provided the original author(s) and source are credited. that there is a positive relationship between displacement length and the peak of flood events, as well as a positive relationship between log velocity and the flood magnitude. Also, a critical flow rate over which logs stranded on active bars can be transported has been identified. The ability to predict wood mobility in gravel-bed rivers could allow to define better strategies of river management and restoration, by improving the ability to understand wood transport processes and calibrate budgets of wood in rivers.

\section{Introduction}

Wood is an important component of river systems, as it could contribute to determine geomorphic (Brookes, 1988), hydraulic, and ecological processes (Gurnell et al., 2002; Sedell et al., 1988). Despite some positive effects in river systems, wood in-channel could represent an issue to some human activities on rivers, as it may disrupt navigation, including commercial marine operations on large rivers (Gurnell et al., 2002; Piégay, 2003) and also might damage infrastructure when it accumulates on or near sensitive structures as bridge piers for example increasing bridge scour (Diehl, 1997; Wallerstein, 1998; Kothyari and Ranga Raju, 2001). Wood budgeting in mountain basin is thus of the highest importance in terms of morphodynamics studies of river systems and hazard mapping of floodplains and critical areas (bridge, in-channel structures, etc). However, a there still a considerable lack of knowledge on the complex set of processes involved in the recruitment, transport, deposition, and decay of wood pieces in fluvial systems, and even more on the quantification of these processes at the rage of spatial and temporal scales at which they occurred. Some previous studies have attempted to assess wood budget in mountain catchments trying to give a conceptual framework on how to approach the budgeting (Benda et al., 2003; Martin \& Benda et al., 2001; Marcus et al., 2011; MacVicar and Piégay, 2012) but there is a lack of knowledge on some factors on the formulas. In particular, entrainment threshold for log movement and displacement lengths during floods of different magnitude are still poorly quantified and scarcely measured in the field.

Recently, Marcus et al., 2011 proposed an annual wood budget using a relation between transport rate and flow discharge. Beside, in the French Rhone River, Moulin and Piégay, (2004a) found a positive correlation between flood magnitude and volumes of transported. More recently, MacVicar \& Piégay (2012) used a streamside video cameras to observe wood transport during floods, and correlated it with the water discharge in a wandering piedmont river, the Ain River in France. Other studies (Braudrick et al., 1997; Braudrick and Grant, 2001; Haga et al., 2002) investigated the relationship between the distance travelled by a single piece of wood and the local properties of the flow, observing that the travel distance depends on the wood size (i.e. length or diameter) and density, the water depth and velocity, and the channel bed roughness. Physical modelling of wood transport and displacement lengths with steady flow condition were carried out by Bocchiola et al. (2006a) and Bocchiola et al. (2008), who also explored 
the behavior of logs in presence of obstacles.

This paper presents some novel data on log incipient motion and displacement lengths during floods of different magnitude in a large, braided gravel-bed river of the Eastern Italian Alps (Tagliamento).

\section{Studyarea}

This research was carried out in Tagliamento River, a braided gravel-bed river located in Friuli region in north-eastern Italy. The Tagliamento River has a basin area of $2871 \mathrm{~km}^{2}$ and drains for about $172 \mathrm{~km}$ from the Italian Alps (1195 m a.s.l.) to the Adriatic Sea (Figure 1). The river has a straight course in the upper part, while most of its course is braided shifting to meandering in the lower part where dykes have constrained the lower $30 \mathrm{~km}$. In the study reach, the river flows in a width of about $800 \mathrm{~m}$ and with a slope of about $0.003 \mathrm{~mm}^{-1}$.

A strong gradient exists along the length of the river which has a big influence on precipitation, temperature, humidity and consequently vegetation patterns. In fact in the Tagliamento River there is an annual precipitation ranges from 3100 to $1000 \mathrm{~mm}$ per year and mean annual temperature from 5 to $14^{\circ} \mathrm{C}$. Peak river flows usually occur in spring and autumn due to snowmelt and intense precipitation respectively.

The Tagliamento River is one of the few European gravel-bed rivers still retaining a highly dynamic nature and ecomorphological complexity because of a relatively low human impact (Tockner et al., 2003), it is considered as the last morphologically intact river in the Alps and is an ecosystem model for large temperate rivers indeed, along most of its course, the river is enclosed by riparian woodland dominated by Populus nigra and Salix alba (Bertoldi et al., 2013; Francis et al., 2008) especially along the margins and on the many islands within the active, increase the supply of LW in-channel. Whereas the gravel bar surfaces stored 1-6 tha $\mathrm{a}^{-1}$ of wood and vegetated patches stored more than 1000 $\mathrm{t} \mathrm{ha} \mathrm{a}^{-1}$. However, it was observed in study area through field survey a wood storage of $6 \mathrm{t} \mathrm{ha}^{-1}$ (Gurnell el al., 2000).

\section{Materials and methods}

Log mobility was studied from June 2010 to October 2011, a period characterized by a relatively high magnitude flood in November 2010 recorded at Villuzza's gauging station (Figure 2). Woody elements of different size and typology were measured to analyses the log mobility and displacement length during flood events. Active radio transmitters (RFID) and LandAirSea's 3100-EXT passive GPS track (below called GPS track) devices were implanted in 113 and 42 logs respectively (Figure 3).

RFID devices, the same tested in Ain River by MacVicar et al. (2009), were installed in little holes on the trunk and they were isolated from the water by a cover of silicone. These devices allow to recover the log after flood events by using a portable antenna, and to derive the displacement length over the monitoring period, whereas the GPS track allows calculating instantaneous (1 sec) and average log velocity of moving logs. These devices, never tested in rivers before, have dimensions in $\mathrm{cm}$ of $8.64 \mathrm{~W}$ x $10.67 \mathrm{~L} \mathrm{x} 4.32 \mathrm{H}$ and powered by 4AA batteries. They are equipped with an external GPS antenna and up to 300 hours of internal GPS flash data storage-tracking capacity. The devices have a cold start GPS acquisition time, warm start and hot start GPS of 90, 50 and $<10$ seconds respectively. Each GPS track was waterproofed using a plastic box , where a RFID was placed as well in order to allow postevent recovery. Plastic boxes were fixed to woody elements tying them to the trunk with metal chains and cable ties.

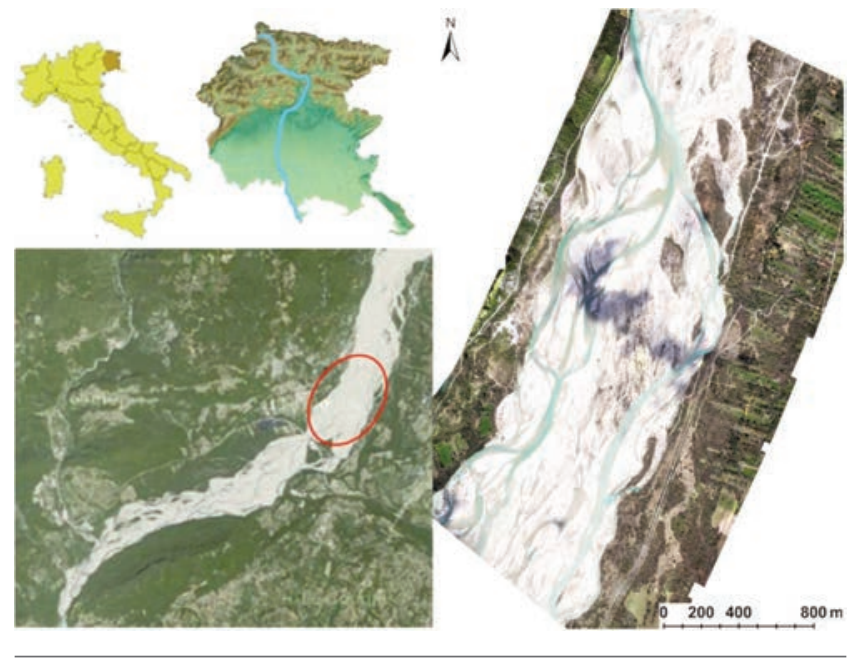

Figure 1. Location of Tagliamento river and the Cornino sub-reach.

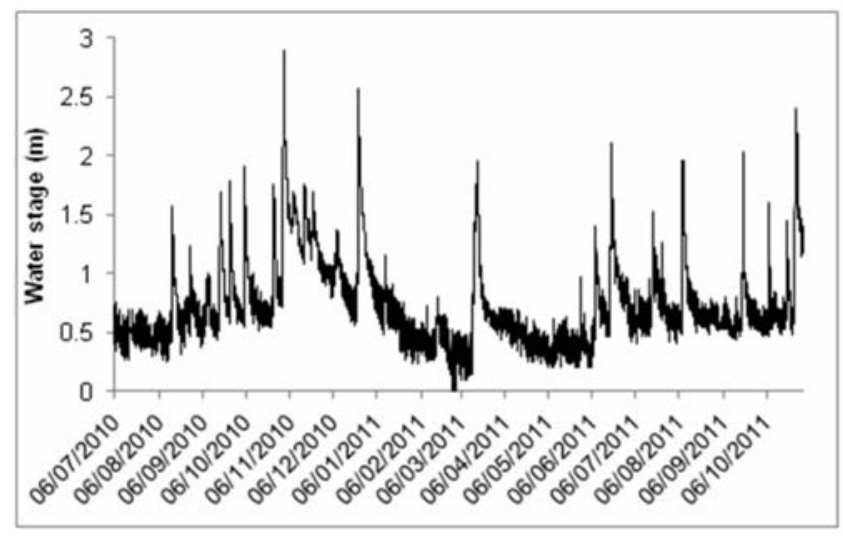

Figure 2. Water stage recorded at Villuzza's gauging station in Tagliamento river.

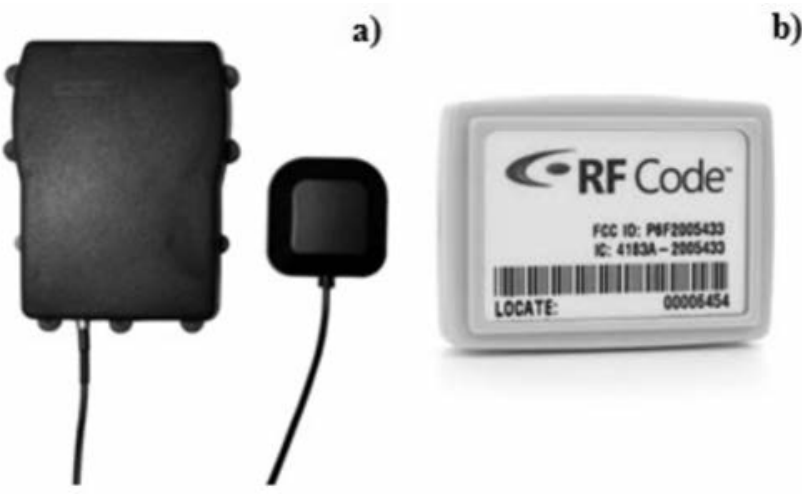

Figure 3. Example of the different devices installed on the logs in Cornino sub-reach: LandAirSea's 3100-EXT passive GPS track (a) and Active radio transmitters (RFID) (b). 
The devices were installed at three different times during the study period. 21 GPS track and 75 RFID were installed in August 2010, further 7 RFID and 6 GPS were installed in December 2010, and lastly, 31 RFID and 15 GPS were installed in March 2011.

All the woody elements were tagged in low bars (Rinaldi, 2000) in order to have similar incipient motion conditions. Each tagged log was measured using a spread sheet and the volume was calculated using its mid-diameter and length taken by a tree caliper and tape, respectively (Mao et al., 2008). Additional data concerning tree species, orientation to flow, state of decay, delivery mechanism and position in the channel were collected for each log analyzed. The positions of all tagged log was recorded before and after the flood events using a DGPS Leica series Viva. DGPS data were surveyed and geo-referencing of the same control network (stable points along the floodplain).

\section{Results}

From June 2010 to March 2011, 113 RFID and 42 GPS track were installed in 155 logs. The recovered logs accounted for 56 RFID and 26 GPS track (Table 1). During the flood events of the study period, 31 RFID and 5 GPS track were mobilized. Furthermore, 15 GPS track recorded an activation signal (e.g. the plastic box floated around the $\log$, which was not transported by the flood) but they were not mobilized. On the Figure 4 are indicated the logs with GPS track that have been displaced and the logs which have only been activated but not transported. The highest recorded rates of GPS track activation were recorded on 15/08/2010 and 05/10/2010, with peaks flow high 1.57 and $1.91 \mathrm{~m}$ at Villuzza, respectively. On the other hand, the highest recorded rates of GPS track with movement were recorded on 15/08/2010 and $19 / 06 / 2011$, with peaks flow high of 1.57 and $2.11 \mathrm{~m}$, respectively. GPS_8a was transported for more than $51000 \mathrm{~m}$ during the flood event of the $19 / 06 / 2011$.

Most of the tagged logs, were entrained during the rising limb or at the peak of the hydrographs. Also, most of the immobile GPS tracks have recorded a signal of activation during the rising limb of the lowest floods. It is important to note that during the falling limb of the flood event in November 2010, the GPS_4 recorded two signals of movement, 03/11/2010 and 06/11/2010 respectively.

The median value of the flow which have activated but not moved the logs with GPS track installed is around $38 \%$ of the bankfull stage, whereas a $40 \%$ of bankfull stage is required to entrain the tagged logs.

To assess the relation between high flow discharge and logs displacement length, the flow duration curves have been calculated, taking into account the whole period in which the RFID remained installed in the field before being recovered, and the period in which GPS Track devices moved. From the flow duration curves, the following percentiles were calculated: $h_{25}, h_{50}, h_{75}$ and $h_{100}$ (i.e. the maximum registered flow stage). Figure 5 shows that there is a certain correlation between the displacement length and the peak of hydrograph that caused the entrainment. Beside, this relationship increased in statistical significance if $h_{25}$ and $h_{75}$ are taken into account as well.

Knowing the log's travel distance and the duration of their movements, it was possible to calculate log's velocity during floods. Because logs could temporarily stop during the events, their velocity is called "virtual velocity", sensu Wilcock (1997). It was observed that there is a relatively poor correlation between the peak of transporting floods and virtual velocity. However, using the $\left(h_{75}-h_{25}\right)$ ratio, the regression sensibly increases its statistical significance. Because velocities calculated from data collected by the GPS Track devices is a real velocity, as it considers only the interval in which the log actually moved, it is surprising that there appears to be no relation between velocity and the water stage of hydrograph. This is likely due to the reduced number of observation, and to the fact that considerable velocity fluctuations were observed.

\section{Discussion and Conclusions}

A proper assessment of wood budgeting at the basin and reach scale of a river system is crucial for engineering, geomorphological, and ecological purposes. However, the current knowledge of physical processes involved in the recruitment, entrainment, transport and deposition of logs in rivers is very poor due to the complexity of these phenomena and the lack of field observation. This study provides one of the few field evidence of log transport during floods in a wide, braided gravelbed river. Displacement length and virtual velocity data have been col-

Table 1. Summary of recovery rate of GPS Track and RFID devices during the study period.

\begin{tabular}{|c|c|c|c|}
\hline \multicolumn{2}{|c|}{$\begin{array}{c}\% \\
\text { Lost }\end{array}$} & $\begin{array}{c}\text { GPS Track } \\
38.1\end{array}$ & $\begin{array}{r}\text { RFID } \\
50.4\end{array}$ \\
\hline Found & Moves & 11.9 & 27.4 \\
\hline Found & Immobile & 50 & 22.1 \\
\hline
\end{tabular}

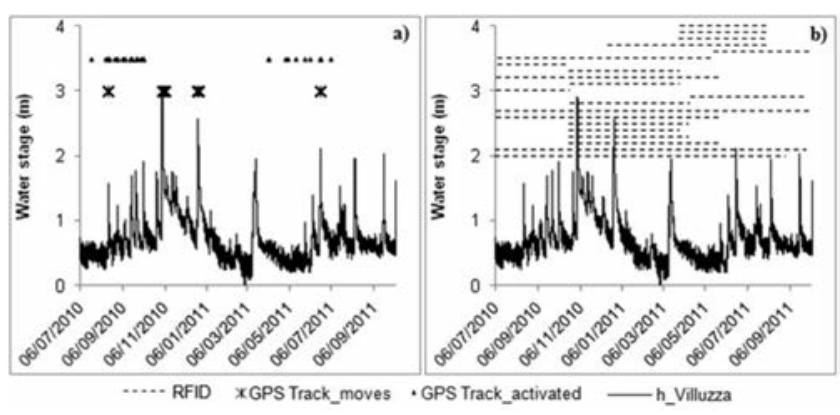

Figure 4. Flood events during the study period with the identification of the activation and displacement of the GPS Track devices (a) and the installation days and recovery of RFID devices (b).

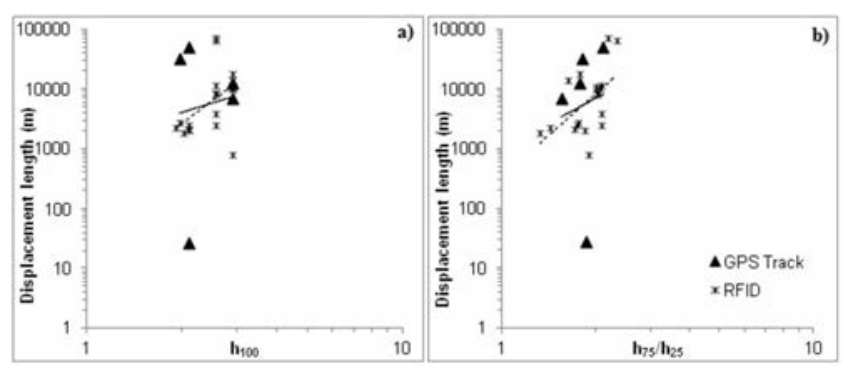

Figure 5. Power trend lines that analyze the relation between logs displacement length in function of the percentile 100 of the GPS Track and RFID flow duration curves (GPS Track $R^{2}=0.0102$ RFID $R^{2}=0.2399$ ) (a) and in function of the ratio between the percentiles 75 and 25 (GPS Track $R^{2}=0.0107$ RFID $\left.R^{2}=0.3011\right)(b)$. 
lected using active radiotransmitters (RFID) and GPS antennas with dataloger fixed to logs lying on low, active bars. The devices proved to work reasonably well, as the recovery rate was quite high, and comparable with what reported by MacVicar et al. (2009). Large wood transport has been recently analyzed by MacVicar and Piégay, (2012) using a video camera fixed to the bank of a river, and a LSPIV tracking software. Even if this method does not work overnight, it allowed to observe that $\log$ transport is higher during the rising limb of hydrographs. This has been verified in the Tagliamento as well, and is likely to be related to the transport of ready-available logs stranded in the low bars. As expected, logs are likely to be deposited in low bars during the falling limb of hydrographs, at a lower discharge than the required for its entrainment. As to the relationship between wood transport and flood peak magnitude, the study suggests that there is a poor direct correlation. This is in agreement with what previously observed by Moulin and Piégay (2004a) and modeled by Marcus et al. (2011), who suggested that this relationship is highly non-linear.

This preliminary results reported in this study are to be enriched by further time series analysis and an attempt of numerical modelling, but represent one of the first attempts of measuring log entrainment, travel distance and velocity in a gravel-bed river in Italy. Further studies could increase our current understanding of these processes in rivers, with important practical applications such as risk analysis in floodplains, design of in-channel structures, and river ecology application.

\section{References}

Benda LE, Sias JC. A quantitative framework for evaluating the mass balance of in-stream organic debris. In: Forest Ecology and Management, 172; 2003. pp 1-16.

Bertoldi W, Gurnell AM, Welber M. Wood recruitment and retention: The fate of eroded trees on a braided river explored using a combination of field and remotely-sensed data sources. In: Geomorphology, 180-181; 2013. pp 146-155.

Bocchiola D, Rulli MC, Rosso R. Transport of Large Woody Debris in the presence of obstacles. In: Geomorphology, 76; 2006a. pp 166-178.

Bocchiola D, Rulli MC, Rosso R. A flume experiment on the formation of wood jams in rivers. In: Water Resources Research, 44; 2008. pp 17.

Braudrick C.A, Grant G.E, Ishikawa Y, Ikeda H. Dynamics of wood transport in streams: a flume experiment. In: Earth Surface Processes and Landforms, 22; 1997. pp 669-683.

Braudrick CA, Grant GE. Transport and deposition of large woody debris in streams: a flume experiment. In: Geomorphology, 41(4); 2001. pp 263-283.

Brookes A. Channelized Rivers, Perspectives for Environmental Management. In: Wiley, New York; 1988. pp 362.

Diehl TH. 1997. Potential drift accumulations at bridges. US Department of Transportation, Federal Highway Transportation.

Francis RA, Petts GE, Gurnell AM. Wood as a driver of past landscape change along river corridors. In: Earth Surface Processes and Landforms, 33; 2008. pp 1622-1626.

Gurnell AM, Petts GE, Hannah DM, Smith BPG, Edwards PJ, Kollmann
J, Ward JV, Tockner K. Wood storage within the active zone of a large European gravel-bed river. In: Geomorphology, 34; 2000. pp $55-72$.

Gurnell AM, Piégay H, Swanson FJ, Gregory SV. Large wood and fluvial processes. In: Freshwater Biology, 47; 2002. pp 601-619.

Haga H, Kumagai T, Otsuki K, Ogawa S. Transport and retention of coarse woody debris in mountain streams: An in situ field experiment of log transport and a field survey of coarse woody debris distribution. Water Resources Research, 38; 2002. pp 1126.

Kothyari UC, Ranga Raju KG. Scour around spur dikes and bridge abutments. In: Journal of Hydraulic Research, 39(4); 2001. pp 367-374.

MacVicar BJ, Piégay H. Implementation and validation of video monitoring for wood budgeting in a wandering piedmont river, the Ain River (France). In: Earth Surface Processes And Landforms, 37; 2012. pp 1272-1289.

MacVicar BJ, Piégay H, Henderson A, Comiti F, Oberlin C, Pecorari E. Quantifying the temporal dynamics of wood in large river: field trials of wood surveying, dating, tracking, and monitoring techniques. In: Earth Surface Processes and Landforms, 34; 2009. pp 2031-2046.

Mao L, Burns S, Comiti F, Andreoli A, Urciolo A, Gavino-Novillo M, Iturraspe R, Lenzi MA. Acumulaciones de detritos lenosos en un cauce de Montaña de Tierra del Fuego: Analisis de la movilidad y de los efectos hydromorfologicos. In: Bosque, 29 (3); 2008. pp 197-211.

Marcus WA, Rasmussen J, Fonstad MA. Response of the fluvial wood system to fire and floods in northern Yellowstone. In: Annals of the Association of American Geographers, 101; 2011. pp 22-44.

Martin DJ, Benda LE. Patterns of instream wood recruitment and transport at the watershed scale. In: Transactions of the American Fisheries Society, 130; 2001. pp 940-958.

Moulin B, Piégay H. Characteristics and temporal variability of large woody debris trapped in a reservoir on the River Rhone (Rhone): implications for river basin management. In: River Research and Applications, 20; 2004a. pp 79-97.

Piégay H. Dynamics of wood in large rivers. In: Gregory, S.V., Boyer, K.L., Gurnell, A.M. (Eds.), The Ecology and Management of Wood in World Rivers. American Fisheries Society, Bethesda, MD; 2003. pp $109-134$.

Rinaldi M. 2000. "Erosione del suolo, fenomeni franosi e dinamica fluviale". Dispense del corso di Geologia Applicata. Università degli studi di Firenze. Corso di Laurea in Ingegneria per l'Ambiente e il Territorio. pp. 180.

Sedell J.R, Richey J.E, Swanson F.J. The river continuum concept: a basis for the expected ecosystem behavior of very large rivers? In: Canadian Special Publication of Fisheries and Aquatic Sciences, 106; 1989. pp 49-55.

Tockner K, Ward JV, Arscott DB, Edwards PJ, Kollmann J, Gurnell A.M, Petts GE, Maiolini B. The Tagliamento River: a model ecosystem of European importance. In: Aquatic Sciences, 65; 2003. pp 239-253.

Wallerstein NP. Impact of LWD on fluvial processes and channel geomorphology in unstable sand bed rivers. $\mathrm{PhD}$ thesis, University of Nottingham, UK; 1998.

Wilcock PR. Entrainment, displacement and transport of tracer gravels. In: Earth Surface Processes and Landforms, 22; 1997. pp. 11251138. 